\title{
Postmaterialism and young people's political participation in a time of austerity
}

Matt Henn (corresponding author)

email:matt.henn@ntu.ac.uk

telephone: +44 (0)115 8488156

\section{Ben Oldfield}

email: ben.oldfield@ntu.ac.uk

\section{James hart}

email: james.hart2015@my.ntu.ac.uk

School of Social Sciences,

Nottingham Trent University,

50 Shakespeare Street,

NOTTINGHAM,

NG1 4FQ

\begin{abstract}
Recent trends suggest that young people in Britain are refraining from engaging in formal political processes. At the same time, they are increasingly expressing support for, and turning toward, a new and diverse range of non-institutionalised forms of political action in order to actualise their interests. Using Inglehart's ideas on postmaterialism, we consider whether this apparent rejection of mainstream politics in favour of less conventional - and sometimes radical - forms of political action is changing over time in Britain, reflecting fluctuating economic conditions witnessed over the last two decades. We do this by comparing results from surveys of British 18 year olds conducted in 2002 during an era of relative global prosperity, and then in 2011 at the height of the current global crisis. The findings suggest that British young postmaterialists are considerably more likely than materialists to participate in and support both institutionalised and non-institutionalised forms of political action.
\end{abstract}

Keywords: Postmaterialism; Political participation; Young people; Generation

\section{Funding}

This work was supported by the Economic and Social Research Council under Grants R000223598 and RES-000-22-445.

\section{Acknowledgements}

The authors would like to thank Paul Carroll and Sarah Pope at Ipsos MORI, both for their preparation of the data and for their general contribution to the project. Thanks also to Chloe Ferris - an undergraduate student at Nottingham Trent University - for her help with the literature search for the paper. 


\section{Introduction}

Evidence suggests that young people in Britain are becoming progressively more disillusioned with the practice of democratic politics, rejecting the institutions of national government, and consequently leaving democracy in a state of relative crisis (Hay 2007; Whiteley 2012; Tormey 2015). This is most visibly reflected in an emerging pattern of generational electoral inequality that sees young people significantly less likely to vote than their older contemporaries (Berry 2012; Henn and Oldfield 2016). Although there is considerable debate as to the extent to which such developments are permanent or reversible (Flanagan et al. 2012; Phelps 2012), it has been argued that a particular outcome from these processes has been the relative marginalisation of youth by the political class. In effect, politicians have tended to champion the policy concerns of older and other more voting-inclined groups to the detriment of young people which has served to further reinforce their disconnection from formal politics (Furlong and Cartmel 2012; Birch, Gottfried and Lodge 2013; Sloam 2014).

However, it is claimed by some that this persisting withdrawal of British youth from institutionalised politics has its parallel in a tendency towards support for, and participation in, new styles of non-institutionalised political action that better fit their individualised lifestyles and permit the actualisation of their political aspirations (Busse, Hashem-Wangler and Tholen 2015; Soler-i-Marti 2015). This perspective reflects the core assumptions underlying Ronald Inglehart's Postmaterialist thesis (Inglehart 1971) which claim that young people are increasingly rejecting traditional political arrangements and organisational methods in favour of alternative and highly participative modes of political action.

Although a small number of studies have previously considered the growth of postmaterialist preferences among contemporary British youth (Majima and Savage 2007; Sloam 2007; Theocharis 2011), there are to date no large-scale nationally representative studies in this particular field. In this article we address this gap in data and knowledge and test the efficacy of the postmaterialist thesis in terms of helping to explain young people's political participation priorities. Furthermore, there is no published research that has systematically considered the specific impact of recent changes in material-economic context on youth political participation preferences in Britain. Here we compare data from two connected studies to examine a key tenet of the postmaterialist thesis that young people's patterns of support for different forms of political action reflect the underlying economic conditions of their socialisation. The first study was conducted in 2002 at a time of relative economic prosperity. At such a moment, Inglehart's thesis assumes support for postmaterialist political participation methods would be high. The second study was completed in 2011 at the height of the current global economic recession, when the thesis suggests that postmaterialist preferences would be comparatively lower. Finally, we assess the veracity of Inglehart's claim that postmaterialism exhibits greater explanatory power than does socio-demographic background (including gender, ethnicity, social class and educational career) with respect to the structuring of young people's political behaviour.

In this article, we therefore aim to test the value of several key aspects of Inglehart's postmaterialist thesis in helping to explain young Britons' political participation preferences, by addressing three linked research questions: 
- To what extent are young people's views of existing democratic arrangements and their support for different methods of political participation influenced by their materialist-postmaterialist value preferences?

- How important are materialist-postmaterialist value priorities relative to young people's personal socio-demographic backgrounds in shaping their support for different forms of political action?

- Do young people's political participation preferences reflect the underlying conditions of either economic prosperity or economic austerity experienced during their preadult socialisation?

\section{Contemporary patterns of political participation}

Recent trends across Europe indicate that people of all ages seem less committed to national political systems and mainstream political parties, and are increasingly susceptible to radical parties and to their rhetoric (Della Porta 2006; Grimm and Pilkington 2015). They also appear to be deeply sceptical of governments and of the political classes (Norris 2011; Holmes and Manning 2013; Hansard Society 2016). The underlying causes of this political disengagement are much debated. For instance, in Britain, Hay (2007) distinguishes between demand-side and supply-side explanations. Those who prioritise demand-side reasons focus on the changing attitudes of citizens who increasingly hold unrealistic expectations of politicians who are perceived to under-perform (Whiteley 2012). In contrast, supply-side explanations emphasise the nature of contemporary formal politics itself, which is considered remote, inaccessible and largely unappealing to citizens (Hay 2007; Henn and Oldfield 2016).

This apparent rupture between citizens and the institutions of democratic governance is particularly noticeable among young people who seem more disconnected from formal politics than do other age groups in Britain and in other countries (Norris 2011; Sloam 2014). As a consequence, the current youth generation is often decried as apathetic or even as antipolitical (Stoker 2006; Hay 2007). However, young people in Britain are neither antidemocratic nor innately anti-election (Henn and Foard 2014). This is evidenced by the 75 per cent of 16 and 17 year olds who voted at the Scottish Independence Referendum in 2014 (The Electoral Commission 2014), while it is estimated that 64 per cent of registered voters aged 18 to 24 cast a ballot at the 2016 UK referendum on EU membership (Helm 2016). These particular cases suggest that young citizens will take part in formal election-oriented (institutionalised) politics where such contests have critical meaning and value-potential for them. Furthermore, the 2016 EU Referendum demonstrated that young people are a generation apart in terms of their value priorities and identity politics, with a positive vision of Britain's relationship with Europe that was distinct from those of their older and more Eurosceptic contemporaries (Fox 2016). Such attitudes were reflected in the final vote, with 75 per cent of 18 to 24 year olds opting to remain in the EU while the country at large voted to leave by a margin of 52 to 48 per cent (YouGov 2016).

Despite their willingness to vote in these identity-oriented Referenda, young people's participation in UK-wide general elections since the turn of the new Millennium continues to remain noticeably lower than it was during previous decades (Dar 2013). It is also significantly less than for their older contemporaries, with for instance 76 per cent of those aged 65 and 
over voting at the 2015 contest compared to 43 per cent of 18 to 24 year olds - a generational electoral gap of 33 per cent (Ipsos MORI 2015).

Although young people are generationally distinct in terms of their patterns of electorallyoriented participation, it has been argued that this reflects a rejection of formal institutionalised politics and an inclination towards alternative forms of participation, rather than political disinterest per se. For instance, Phelps (2012) has identified an 'anti-apathy' model (Bentley et al. 1999; White, Bruce and Ritchie 2000; Henn, Weinstein and Forrest 2005; Marsh, O'Toole and Jones 2007) that contends that young people are progressively gravitating towards new styles of political participation that are extra-parliamentary in nature, non-hierarchical and considered to be self-actualising and consequently highly efficacious (Beck 1992; Farthing 2010; Furlong and Cartmel 2012). The reconfiguration of political engagement in recent decades (Bauman 1999) reflects the demand-side explanation of political disengagement (see: Hay 2007). The tendency towards individualism in late modernity has meant that people are increasingly rejecting institutional politics in favour of alternative forms of participation (Giddens 1991). The increase in individualised values has a corresponding influence on political behaviour, as people eschew the traditional, hierarchical format of participation in favour of a looser politics which is created from below (Beck and Beck-Gernsheim 2002).

This claim that alternative forms of political participation are replacing traditional modes of engagement has support in a number of studies (Stolle, Hooghe and Micheletti 2005; Li and Marsh 2008). Younger generations are far more likely to take part in non-institutionalised forms of political engagement such as boycotting or attending demonstrations, whereas their older contemporaries prefer institutionalised methods of engagement such as voting (Quintelier 2007; Melo and Stockemer 2014). For instance, while British youth are conspicuous by their declining presence at recent elections, they have been actively participating in extra-parliamentary actions such as the 2010 student protests (Hopkins, Todd and Newcastle Occupation 2011) and the youth-led occupations that took place across the country in 2011 and 2012 (Halvorsen 2012). Furthermore, this apparent expansion of noninstitutionalised political action has been facilitated by developments in social media and online activism (Vromen, Xenos and Loader 2015); in an era of increasingly individualised politics, such online collaboration has facilitated seemingly disparate individuals to unite around personalised causes and coordinate forms of multilateral actions (Parigi and Gong 2014).

\section{Postmaterial political participation}

In many respects, these developing patterns of contemporary political participation were anticipated by Ronald Inglehart's seminal work, The Silent Revolution (1971) which formed the foundation for his postmaterialist thesis. Crucial to this thesis is the centrality of economic forces in shaping citizens' values and behaviours. As the post-war austerity decades came to a close at the end of the 1960s, Inglehart claimed that changing economic conditions were having a profound and transformative impact on political behavioural and value priorities across Europe (Inglehart 1971; Inglehart and Welzel 2005). In particular, while older generations were socialised under conditions of relative economic insecurity into privileging 
materialist concerns, younger adults' formative experiences were of relatively high and stable economic affluence (1971: 991).

Reflecting on these emerging processes, Inglehart claimed that, '...as a result of long-term economic security, an intergenerational value change was taking place from Materialist to Postmaterialist priorities' (Inglehart 1990: 7). Consequently, younger Europeans displayed a preference for higher-order postmaterial concerns such as environmental sustainability and freedom of expression. Furthermore, freed from the urgency of material survival, postmaterialists were typified by a deepening awareness of, and frustration with, the limits of existing democratic arrangements and institutionalised forms of political participation - and more so than their materialist counterparts. Instead, they were attracted to an alternative and transformative politics, advocating political reform while also supporting and participating in new forms and styles of non-institutionalised political action. In some respects, Inglehart's postmaterialist thesis anticipated the demand-side explanation of young citizens' disengagement from formal politics, and the emergence of a less deferential and more critical electorate as characterised in the work of Hay (2007) and Norris (2011). The thesis also offers a potentially valuable theoretical lens for empirically examining the dynamics of contemporary manifestations of youth political behaviour as outlined above.

In addition to its emphasis on underlying economic context, the postmaterialist thesis also challenged existing political science explanations of the time that situated political participation in people's socio-demographic characteristics, including their social class, education, gender and ethnicity (Verba and Nie, 1972). While acknowledging that key variables such as age, social class and education influenced whether individuals developed materialist or postmaterialist value preferences, Inglehart claimed that, over-time, a materialist-postmaterialist cleavage would come to replace such socio-demographic variables as key predictors of political participation (Inglehart 2016).

The postmaterialist thesis has been the subject of considerable controversy, however. In particular, studies have questioned whether a postmaterialist generational shift in political participation preferences has actually occurred. For instance, research conducted by Flanagan and colleagues (2012) suggests that young people are delaying their engagement with politics due to changes in their life-cycle, and that they will begin to participate in formal politics in greater numbers when they have achieved the markers of adulthood - such as homeownership and secure employment - later in life. Grasso's (2014) recent study, which analysed age, period and cohort effects, has cast doubts upon the postmaterialist notion that young people's inclination towards alternative participation is mediated by the prosperity within their society. She concluded that being socialised in a politically volatile era, characterised by strong ideological divisions, is more influential than the affluence of that society in encouraging people to conduct non-institutionalised politics. Contemporary austerity, therefore, may inspire young people to engage with postmaterial values, rather than prioritising material concerns as Inglehart's thesis would suggest.

One key aspect for reflection on the value of Inglehart's thesis is the extent to which it can help with understanding patterns of political participation during periods of economic insecurity as well as economic prosperity - particularly given the longevity of the current global recession. Inglehart has previously conceded that during times of economic downturn, 
the advance of postmaterialist values and support for postmaterialist styles of noninstitutionalised political participation would somewhat reduce (Inglehart and Welzel 2005). Despite such cyclical patterns linked to underlying changes within the economy, there is some evidence to suggest that there has been an increase in the proportion of the population taking part in such alternative activities over the last 35 years as the transformation in political values begins to influence people's political action (Inglehart and Catterberg 2003). Furthermore, academic studies have identified a link between postmaterialist preferences and political consumerism such as boycotting and buycotting which have become an essential ingredient in younger people's political behaviour (Stolle, Hooghe and Micheletti 2005). Those partaking in political consumerism are likely to demonstrate postmaterial preferences, valuing forms of direct action while being dubious of institutionalised politics to deliver results (Copeland 2014). However, the ongoing global economic crisis has served to obfuscate patterns of postmaterialist preferences, and recent research suggests there has been a reduction in postmaterial values and political actions in many countries (Cameron 2013; Brym 2016; Janmaat 2016).

In this article, we consider the veracity of Inglehart's postmaterialist thesis by examining recent patterns of young people's political participation in Britain. This is assessed by a comparison of the results from two linked studies that focus on the political participation preferences of separate cohorts of 18-year-old British youth. The first study was conducted in 2002 during an era of relative global prosperity, whilst the second study was completed in 2011 at the height of the current financial crisis. These represent two distinct economic periods which are important for testing Inglehart's postmaterialist thesis. For instance, data indicate that in 2002, UK GDP annual growth was $2.4 \%$ and had fallen to $1.5 \%$ by 2011 following the onset of the global recession (ONS 2016a). For the same years, wage growth reduced from $2.9 \%$ to $1.6 \%$ (ONS 2016b), and the unemployment rate increased from $5.2 \%$ to $8.1 \%$ (ONS 2016c). By taking two samples across these time periods, we are able to statistically compare whether young people's political participation preferences are also shaped by the economic conditions of their pre-adult socialisation as specified in Inglehart's postmaterialist thesis.

Our hypotheses are:

H1: Levels of dissatisfaction with current democratic arrangements will be higher among young postmaterialists than among other young people.

$\mathrm{H} 2$ : Young postmaterialists will be less likely than their contemporaries to support and take part in institutionalised forms of political participation in the future, and more likely to support and involve themselves in non-institutionalised methods of political action.

H3: The relative weight of young people's materialist-postmaterialist values on their support for and participation in institutionalised and non-institutionalised forms of political participation will be greater where their pre-adult socialisation experiences were gained under conditions of relative economic security than for those socialised under conditions of economic austerity.

H4: Materialist-postmaterialist value preferences will have a greater impact on young people's future patterns of political participation than will socio-demographic variables. 


\section{Research design}

To test these hypotheses, our analyses are based on the examination of two large-scale quantitative datasets previously completed by one of the authors that allow us to consider young people's patterns of political participation over time (see xxxx, 2003; xxxx, 2012)i.

\section{Phase 1: 2002 postal survey}

A representative sample of 705 attainers living in England, Scotland and Wales was obtained via a postal survey conducted in the spring of 2002, one year after the General election of 2001. We selected 18-year-old attainers at this time because that particular election contest was their first ever opportunity to vote. It therefore implied that they were relatively inexperienced in comparison to others who had been eligible to vote at previous elections, and suggested that they were less likely than their contemporaries to have already formed deep-seated views about politics, parties and politicians. This was important because we wanted to assess the views and reactions of this particular age group after they had been granted their first opportunity as newly enfranchised citizens to gain experience of life under a new government. This study did not require participants to have actually voted in the election process.

The electoral register formed the basis for a random sample of the eligible population to be accessed. Standard ACORN categories as defined by the Government Standard Region were used to stratify the sample. A total of 3,109 surveys were distributed to potential participants and 705 completed surveys were returned, representing an overall response rate of $23 \%$.

\section{Phase 2 - 2011 online survey}

The second study comprised a representative sample of 1,025 young people aged 18 at the time of the 2010 UK General Election. The survey was distributed online using a formal polling organisation to embrace modern collection methods and access the largest sample possible. The survey data collection phase was undertaken during April and May 2011 which was one year after the completion of the UK General Election. This was consistent with the 2002 study to minimise unintended variation across the samples.

We are aware that social surveys are not infallible. Polling before the 2015 general election and the 2016 EU referendum proved to be imprecise and did not accurately reflect people's voting preferences or the eventual results. However, in our study we are not making election forecasts. Instead, we are seeking to identify broad clusters of young people with similar values (postmaterialists, materialists and a third 'mixed' group). Furthermore, the trends identified in the 'Findings' section below are consistent across the various political participation indicators and reinforce each other for the materialist-postmaterialist gap.

\section{Independent variables}

We use Inglehart's four-item scale to infer respondents' materialist-postmaterialist value preferences. This scale classifies Materialists as those who prioritise 'maintaining order in the nation' and 'fighting rising prices' while Postmaterialists are those who selected expressive items, including 'protecting freedom of speech' and 'giving people more say in important 
political decisions' (1971, p.994). A third 'Mixed' group comprised those who selected one category from each of these paired responses. Postmaterialists comprise 17.3 per cent of the 2002 sample, while materialists represent 13.5 per cent of the group; the remaining 55.5 per cent are mixed. In the 2011 cohort, the respective figures are 11.4, 27.3 and 53.0 per cent.

In examining the impact of the materialist-postmaterialist variable, we are cognisant of the existence of studies which recognise the value of other variables in potentially structuring political action preferences. For instance, evidence suggests that age completed education (Whiteley 2012), educational qualifications (Tenn 2007), gender (Norris and Inglehart 2009; Furlong and Cartmel 2012), social class (Pattie, Seyd and Whiteley 2004) and ethnicity (Heath et al. 2011) are all important predictors. We examine each of these socio-demographic factors along-side the materialist-postmaterialist variable to assess the relative explanatory weight of each. Social class is measured using the established National Statistics Socio-Economic Classification scheme (NS-SEC). Participants self-reported their social class position and this was defined by the status of the main wage earner in their household rather than their own specific circumstances. This was selected as a better choice as due to the sample age, their personal circumstances would not necessarily be an accurate representation of their true familial social economic circumstances. These categories were composited into whether the main wage earner can be categorised as being managerial/professional (middle class), or not. Whether the participants held educational and vocational qualifications that would be sufficient to provide a route through to higher education are included in the Educational Qualifications variable. Respondents' ethnicity, gender and whether or not they had opted to remain in full time education by the age of 18 rather than leave at an earlier point were also selected as key independent variables.

\section{Dependent variables}

A range of dependent variables which utilised a variety of response formats were employed in the analysis. These included dichotic categorical questions using a simple yes/no format, individual-response multi-category formats and a range of ordinal Likert-type scaled response questions. For all of the categorical analyses conducted, the 'don't know/no answer' response options were treated as missing data and removed from the analysis. This was done in order to be able to analyse only the comparisons between active answers. The 'don't know/no answer' option was also removed from the analyses using the Likert-type response formats. For all scaled response items this category was included as an alternative answer but not part of the scale itself. All analyses using scaled response data excluded this category. For questions using a 5-point Likert-type response format the middle value was included in the analyses.

Several variables were used to indicate respondents' views on existing political processes and arrangements, as well as their support for and intended future participation in different types of political action - both traditional institutionalised methods as well as alternative extraparliamentary non-institutionalised approaches. There is no agreement as how to define these institutionalised and non-institutionalised methods, and we were guided by the typologies of Verba and Nie (1972), Barnes and Kaase (1979), Zukin et al. (2006), Marien, Hooghe and Quintelier (2010), and Sloam (2014). Using principal components factor analyses we subsequently created two factor scales for institutionalised and non-institutionalised 
political actions. These measures were derived from the question, 'Thinking about the next few years, using a scale from $1-5$, where 1 means very unlikely and 5 means very likely. How likely is it that you will:'

Institutionalised actions

1. Vote in the next UK General Election?

2. Vote in the next local council election?

3. Vote in the next election for the European Parliament?

4. Try to convince someone else how to vote?

5. Give money to a political party?

6. Work for a political party or a candidate in an election campaign?

\section{Non-institutionalised actions}

1. Be active in a voluntary organisation, like a community association, charity group, or a sports club?

2. Participate in a protest, like a rally or a demonstration, to show concern about a public issue or problem?

3. Work actively with a group of people to address a public issue or tackle a problem?

4. Discuss politics with family or friends?

5. Get involved in a youth council or forum?

\section{Findings}

The following analyses provide an overview of young people's preferences regarding institutionalised and non-institutionalised forms of political participation, and the extent to which these are related to materialist-postmaterialist priorities. The influence of economic context will also be considered - in particular, whether support for conventional institutionalised and alternative non-institutionalised choices vary according to whether these youth cohorts have been socialised under conditions of relative economic security (the 2002 sample) or economic austerity (the 2011 sample). It will then consider the impact of Inglehart's materialist-postmaterialist cleavage on political action preferences relative to key socio-demographic variables.

\section{Postmaterialism, democracy and extra-parliamentary political action}

The survey results are broadly consistent with expectations from Hypothesis 1, indicating that young people's levels of satisfaction with current democratic arrangements vary according to their materialist-postmaterialist value preferences, with postmaterialists noticeably critical of the status quo and in favour of democratic reform. Overall satisfaction with British democracy is outlined in Table I, with higher mean scores (from 1 to 4) representing higher levels of dissatisfaction. The one-way ANOVA analyses reveal that that young postmaterialists in the 2002 cohort are less satisfied with democracy than are materialists and those from the intermediate 'mixed' group - although the mean differences are not significant. A similar pattern is evident within the 2011 group, although in this case the extent to which postmaterialists are more discontented than are materialists is statistically significant $(p=$ $.003) .^{\mathrm{ii}}$ 
Table II uses Chi-square and demonstrates that there are statistically significant differences in views expressed about the electoral system. Postmaterialists are considerably more likely than their contemporaries to reject the existing voting arrangements and emphasise instead a preference for changing the current first-past-the-post electoral system. Again, the differences are statistically significant in both 2002 and 2011 samples, and fit with Inglehart's claim that postmaterialists will be more likely than other people to embrace reforms designed to extend democratisation of political processes.

\section{Table I about here}

\section{Table II about here}

While critical of existing democratic arrangements, these same young postmaterialists are also decidedly more likely than are their counterparts to approve of alternative noninstitutionalised and extra-parliamentary forms of political participation. Table III summarises the results from one-way ANOVA analyses where lower mean scores (from 1 to 5) imply greater support for a number of such participation methods. The data indicate that young postmaterialists are considerably more likely than other youth to agree that involvement with groups like Greenpeace represents a more effective means for influencing government than does activity in a political party. The group difference is noticeable for the 2002 cohort and statistically significant for the 2011 sample $(p=.003)$. Furthermore, data from the 2011 survey reveal that postmaterialists are also much more likely than are other groups to prioritise involvement with direct action groups over political parties, and this difference is statistically significant $(p<.001)$. iii Finally, a similar pattern is evident on the question of whether or not people should be allowed to organise public meetings in protest against the government. Again, the differences are statistically significant, with young postmaterialists much more likely to express agreement with such a notion than other young people, and this is the case for both 2002 and 2011 cohorts.

\section{Table III about here}

Taken together, the findings in Tables I, II and III align with Inglehart's thesis and Hypotheses 1 and 2. Postmaterialists in Britain are particularly frustrated with existing democratic arrangements, and considerably more supportive of extra-parliamentary forms of political action than are materialists and those from the mixed group. Interestingly, the distinctiveness of the postmaterialists is much more evident for the 2011 'austerity' sample than for the 2002 'prosperity' group, and this runs counter to Inglehart's expectation in Hypothesis 3 that the materialist-postmaterialist divide will be more evident during periods of relative economic affluence than during times of comparative economic downturn. It does, however, evidence the enduring strength of postmaterialism as a force in shaping young people's views on these matters in contemporary Britain, and this accords with Inglehart's expectation that postmaterialist priorities would persist even during times of economic insecurity. 


\section{Postmaterialism and participation in institutionalised and non-institutionalised forms of political action}

Not only is there variation in young people's levels of support for democratic arrangements and different styles of political participation, but there are also differences in terms of the extent to which they express intentions to take part in political actions in the future. Figure I summarises mean scores ( 1 to 5 ) for the six electorally-oriented institutionalised political participation variables and the five alternative non-institutionalised variables. In terms of institutionalised methods of political participation, the data indicate high mean scores for future voting turnout at national, local and European contests, each of which is above the mid-point of 2.5 for both the 2002 and 2011 samples. However, young people express relatively little intention to directly support political parties - whether in terms of trying to convince someone else how to vote, donating money to them, or campaigning for a party or an election candidate. We would expect this, given the findings in previous research that while broadly supportive of democratic processes in principle, young people are dissatisfied with the outcomes from such processes in practice, and are particularly antipathetic of parties and the political class in general (Bastedo 2015).

Patterns of likely future participation in non-institutionalised political activity are equally mixed. Young people are considerably more likely to express future intentions to discuss politics with friends and family and to participate in voluntary organisations, than they are to take part in political actions such as protests, collective actions to address issues of public concern, or involvement in youth councils or forums. This is perhaps not surprising in that these are relatively more demanding as they involve higher levels of intensity, commitment, risk and energy (Marien, Hooghe and Quintelier 2010).

\section{Figure I about here}

There are clear differences between the political activity likelihood scores of the two sample groups over time. Independent t-test analyses indicate that - with the exceptions of voting in future national elections and activity in voluntary organisations - the 2011 youth cohort are statistically significantly more likely than the 2002 group to express an intention to take part in all of the institutionalised and non-institutionalised political actions addressed. It may be that this reflects a generalised discontent with austerity policies introduced by the UK government following the onset of the 2008 global recession, and a desire by young people to consider participating in different forms of political action to challenge the social and economic disparities that have had a disproportionately negative impact on the youth population (Birch, Gottfried and Lodge 2013; Grasso 2014).

Using a one-way ANOVA, the data indicate that these intentions to participate in different modes of political activity are affected by young people's materialist-postmaterialist value preferences. Table IV summarises the interactions between the materialist-postmaterialist variable and the six institutionalised and five alternative non-institutionalised political participation variables. In line with Inglehart's thesis and the expectations of Hypothesis 2, young postmaterialists in Britain are considerably more likely than are their counterparts to express an intention to participate in extra-parliamentary non-institutionalised activities at some point in the near future. This is the case for all such variables for the 2002 cohort who were sampled during the context of relative economic prosperity. Perhaps surprisingly, 
comparisons are also statistically significant for the 2011 sample in all bar one case; the only exception is the item, 'Be active in a voluntary organisation, like a community association, charity group, or a sports club' (although the $p$ value of .082 is close to the $p \leq 0.05$ statistical significance threshold). This suggests that even after the shift to deep austerity conditions prompted by the 2008 global financial crisis, young British postmaterialists are considerably more receptive to extra-parliamentary non-institutionalised modes of political action than are materialists and the mixed groups. This runs counter to Hypothesis 3 which would expect a relative weakening in the impact of the materialist-postmaterialist cleavage during such a transition in economic conditions.

Somewhat contrary to Inglehart's thesis and to Hypothesis 2 that young postmaterialists would eschew traditional electoral politics in favour of extra-parliamentary actions, the data suggest that this group is more likely than are their contemporaries to express the ambition to take part in several of the institutionalised political activities. For the 2002 prosperity sample, these include their plans to vote in future local council and European Assembly elections, as well as the intention to try to convince someone else how to vote. For the remaining items, postmaterialists are more likely to participate than are materialists and those in the mixed group, although the differences are not statistically significant. A similar pattern is revealed for the 2011 sample in that postmaterialists are more inclined towards all such conventional forms of political action than are other young people. The mean differences are statistically significant in all cases except for the two items, voting in national and local council elections.

\section{Table IV about here}

Table $\mathrm{V}$ allows us to directly examine the notion as set out in Hypothesis 3 that support for different forms of political action will reflect the material circumstances prevalent in societies at any one time. Using univariate ANOVA, this compares materialists' and postmaterialists' mean scores for both institutionalised and non-institutionalised forms of political action over time. The data reveal that there are no significant differences between the two cohorts for either the institutionalised $(p=.912)$ or the non-institutionalised $(p=.511)$ political actions. This suggests that contrary to Hypothesis 3, the materialist-postmaterialist cleavage is no more or less evident under the 2011 austerity conditions than during the period of relative economic security experienced by the 2002 cohort.

\section{Table $\mathrm{V}$ about here}

\section{Postmaterialism, socio-demographic background and political participation}

The analyses so far indicate that the materialist-postmaterialist variable strongly interacts with young people's institutionalised and non-institutionalised participation inclinations. Table VI reports the results from analyses using hierarchical regression to address Hypothesis 4. It tests the power of this postmaterialist variable relative to personal socio-demographic factors in terms of structuring young people's preferred methods of political action. The data also allow for an examination of Hypothesis 3, whether any such patterns correlate with the 
shift in economic circumstances witnessed from the 2002 context of relative affluence to the 2011 austerity period.

The results reveal that the materialist-postmaterialist variable has a strong predictive impact on both institutionalised and non-institutionalised methods of political participation, and this is evident in nearly all cases and for both time periods examined. The only exceptions for the 2002 cohort are that the variable has no statistical bearing on either voting in UK national elections or working for a political party; in the 2011 sample, such relationships are present for all variables except for trying to convince someone else how to vote and being active in a voluntary organisation.

The materialist-postmaterialist variable also exercises greater explanatory impact than any of the socio-demographic factors considered, and this is the case for both the 2002 'economic prosperity' cohort and also for the 2011 'austerity' sample. There is some limited evidence of a gender gap for the 2002 group, although this is not consistent; young females are more likely to state an interest in trying to convince someone else how to vote, while males are more likely to express an intention to donate money to a political party. For the 2011 sample, males are more likely than females to consider working actively with others to address a public issue, discuss politics with others, and to get involved with a youth council or forum. Ethnicity displays a strong effect only for the 2011 cohort, with white youth more likely than those from BME backgrounds to participate in five of the eleven methods of political action. There is also some evidence of enduring impact exerted by social class for both samples. Young people from managerial/ professional households are more likely than working class youth to declare intentions to vote in future elections (2002 and 2011 groups) and to convince someone else how to vote (2002 group). However, social class is predictive only of a small number of the non-institutionalised political participation variables, including activity in voluntary organisations (2002 and 2011 samples) and discussing politics with friends and family (2002 cohort).

Interestingly, the two education variables display different degrees of impact on intended political participation activity. Holding higher educational and vocational qualifications is predictive only of voting in UK general elections (2002 and 2011), getting involved with a youth group or forum (2002) and discussing politics with others (2011). In contrast, whether or not young people had opted to remain in full time education beyond the age of 18 exerts a considerably broader impact on future political participation plans. This is the case with respect to voting (2002 and 2011 samples), but also to several of the non-institutionalised political action variables in 2002 (voluntary activities and also discussion with family and friends) and especially so in 2011 (with the exception of activity in voluntary organisations). However, the predictive power of this particular educational variable is considerably less than is the influence of the materialist-postmaterialist variable.

Together, the findings reported in Table VI seem to correspond with Inglehart's thesis that the materialist-postmaterialist cleavage would, in time, begin to eclipse the explanatory power of such socio-demographic variables as a predictor of youth political behaviour in contemporary Britain. None of the socio-demographic variables exert such an impact as the materialist-postmaterialist variable on either the institutionalised or the non-institutionalised methods of political participation. This is particularly the case for the 2002 sample, and this 
fits the thesis that postmaterialism will be particularly evident during periods of relative economic prosperity. However, that the materialist-postmaterialist variable continues to exert at least as much power as any of the socio-demographic variables for the 2011 sample (when respondents were socialised during a period of relative economic austerity), contradicts Hypothesis 3. Nonetheless, it is also indicative of the enduring nature of postmaterialism, and therefore coincides with Inglehart's claim (2016) that postmaterialist values would continue to shape political behaviour even during periods of economic insecurity.

\section{Table VI about here}

\section{Conclusion}

The evidence presented in much political sociology points to a youth generation in contemporary Britain that is progressively withdrawing from formal democratic politics (Sloam 2014; Birch, Gottfried and Lodge 2013). This is particularly noticeable in terms of their lack of participation in institutionalised politics, and especially their absence from voting at elections since 2001. However, whether this pattern of electoral non-participation is indicative of a generalised political apathy amongst young people is open to debate. In particular, there is a considerable body of research suggesting that young people are positively rejecting formal electorally-oriented politics because they feel marginalised by the political class, and alienated from democratic institutions (Berry 2012; Henn and Oldfield 2016). Instead, British youth appear to be increasingly attracted to alternative modes of noninstitutionalised political action such as political consumerism, protests and direct action (Stolle, Hooghe and Micheletti 2005; Melo and Stockemer 2014). Such political actions are considered to be particularly efficacious and appealing to young people as they provide a style of politics that is accessible, flexible and participative (Furlong and Cartmel 2012); they also allow avoidance of the hierarchical approaches endemic in existing electoral politics and reflected in the practices of many mainstream political parties. Consequently, it is argued by some that such repertoires of political action seem to better fit the individualised life-styles of the contemporary youth generation and present greater transformative prospects for selfactualisation (Soler-i-Marti 2015).

The findings from this study reveal that today's youth generation in Britain is attracted to such non-institutionalised methods of political action. However, the pattern is not uniform. In line with Inglehart's thesis and with Hypothesis 1, young postmaterialists appear to be particularly critical of the way that democracy operates in this country, and are especially supportive of plans to reform the electoral system that are intended to reduce the hegemony of the traditional political parties and enhance the prospects of smaller competitor parties. They are also considerably more tolerant of extra-parliamentary protest actions and are more open to the value of pressure group activity and direct action than are their contemporaries.

The data also lend partial support to Hypothesis 2. Young people's support for, and intended future participation in, institutionalised and non-institutionalised forms of political participation reflects their materialist-postmaterialist value preferences. Young postmaterialists are certainly more inclined towards extra-parliamentary and noninstitutionalised political repertoires than are other young people, and the differences 
between these groups are statistically significant. However, somewhat contrary to Inglehart's thesis, this same group of young postmaterialists are also noticeably more predisposed than their contemporaries to institutionalised political participation methods. The expectation from Hypothesis 2 is that this group of young citizens would reject such electorally-oriented methods as having little efficacy and self-actualisation potential; however, contrary to this notion, the evidence from this study indicates that young postmaterialists value such methods considerably more than do other young people. This is particularly interesting for the 2011 sample, especially so given that the programmes on offer from the main political parties represented broadly similar variants of austerity. However, this may reflect a particularly critical response from these young postmaterialists who are prepared in the future to partake in any form of political action - whether institutionalised or non-institutionalised - if such methods offer a means to challenge recent government austerity policies which have had a disproportionately negative impact on the British youth generation.

Interestingly, there is little evidence to support Hypothesis 3 that the relationship between materialist-postmaterialist value preferences and political participation orientations is contingent upon the prevailing economic conditions during pre-adult socialisation. The data indicate that postmaterialist values continue to endure as the economy transitions from a context of relative security to one of austerity following the onset of the current global recession. Although Hypothesis 3 is therefore not confirmed, these findings do suggest by implication that Inglehart's postmaterialist thesis has ongoing theoretical and explanatory value with respect to British youth in contemporary context, even under conditions of economic austerity. Moreover, the materialist-postmaterialist variable exerts considerably greater predictive power in structuring young people's patterns of political participation than do the socio-demographic variables considered as part of this study. Gender, ethnicity, social class, qualifications and educational trajectory each display an important bearing on political participation orientation, but the evidence presented reveals that in line with Hypothesis 4, materialist-postmaterialist value preferences exert significantly greater comparative impact on young people's political participation inclinations.

In conclusion, it would seem that alongside their deepening disconnection from mainstream democratic politics, young Britons are also becoming increasingly open to postmaterialist ideas and attracted to different forms of political action that allow them to pursue their aspirations for meaningful political change. This reflects the demand-side explanation for levels and patterns of political participation which is rooted in changing values and the emergence of a critical youth citizenry. Taken together, our findings suggest that Inglehart's postmaterialist thesis maintains importance and relevance in helping us to understand the dynamics of young people's political engagement and participation in contemporary Britain. This is the case even under existing economic austerity conditions which are usually theorised as less conducive for the transmission of postmaterialist values and political participation preferences. 
Figure I: Mean likelihood of taking part in political action in the next few years (1-5 scale, where 1 means very unlikely and 5 means very likely)

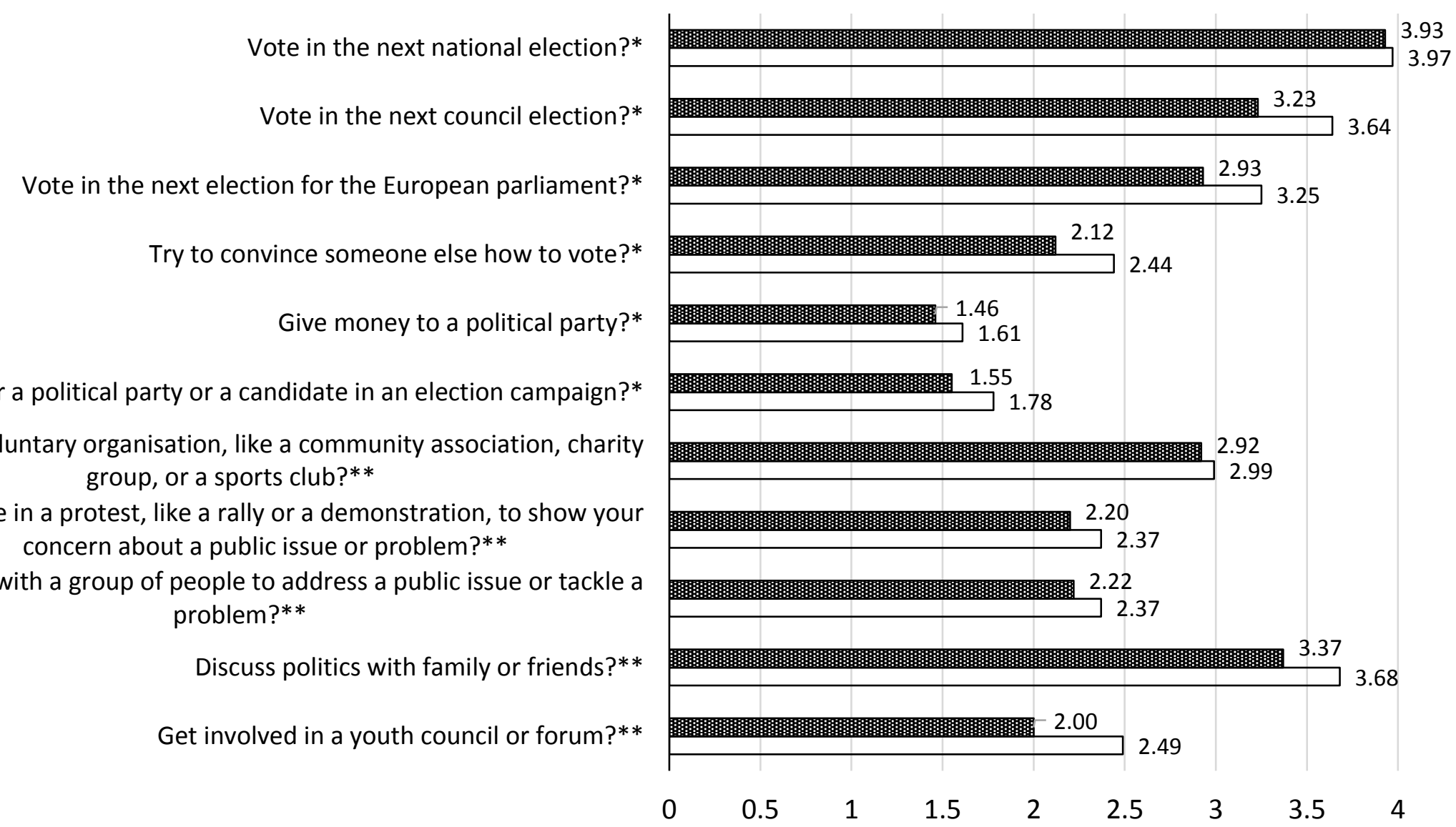

瞰 $2002 \square 2011$

* Election-oriented institutionalised political participation variables

** Alternative non-institutionalised political participation variables 
Table I: On the whole, are you satisfied or dissatisfied with the way that democracy works in this country?

\begin{tabular}{|c|c|c|c|}
\hline \multicolumn{2}{|c|}{ Satisfaction with democracy in this country } & \multirow{2}{*}{$\begin{array}{r}\text { Mean } \\
2.52\end{array}$} & \multirow{2}{*}{$\begin{array}{r}\text { SD } \\
.752\end{array}$} \\
\hline \multirow{4}{*}{2002} & Materialist & & \\
\hline & Mixed & 2.50 & .653 \\
\hline & Postmaterialist & 2.63 & .758 \\
\hline & & & \\
\hline \multirow{4}{*}{2011} & Materialist & 2.29 & .639 \\
\hline & Mixed & 2.42 & .723 \\
\hline & Postmaterialist & 2.56 & .740 \\
\hline & & & \\
\hline
\end{tabular}

Table II: Some people say that we should change the voting system to allow smaller political parties to get a fairer share of MP's. Others say that we should keep the voting system as it is to produce effective government. Which view comes closer to your own?

\begin{tabular}{|c|c|c|c|c|c|}
\hline \multicolumn{3}{|c|}{ Perceptions of the voting system } & \multirow{2}{*}{$\begin{array}{r}\text { Materialist } \\
22.9\end{array}$} & \multirow{2}{*}{$\begin{array}{r}\text { Mixed } \\
33.6\end{array}$} & \multirow{2}{*}{$\begin{array}{r}\text { Post } \\
\text { materialist } \\
44.6\end{array}$} \\
\hline \multirow{7}{*}{2002} & \multirow{2}{*}{$\begin{array}{l}\text { We should change the voting } \\
\text { system }\end{array}$} & Per cent & & & \\
\hline & & Standardised Residual & -1.6 & -.2 & 1.8 \\
\hline & \multirow{2}{*}{$\begin{array}{l}\text { We should keep the voting } \\
\text { system as it is }\end{array}$} & Per cent & 45.7 & 37.1 & 28.7 \\
\hline & & Standardised Residual & 1.3 & .2 & -1.3 \\
\hline & \multirow{3}{*}{ It would make no difference } & Per cent & 31.4 & 29.3 & 26.7 \\
\hline & & Standardised Residual & .4 & .1 & -.4 \\
\hline & & $N=478$ & $\chi^{2}=9.476$ & $p=.050$ & \\
\hline \multirow{7}{*}{2011} & \multirow{2}{*}{$\begin{array}{l}\text { We should change the voting } \\
\text { system }\end{array}$} & Per cent & 23.8 & 36.7 & 59.1 \\
\hline & & Standardised Residual & -2.8 & .2 & 3.6 \\
\hline & \multirow{2}{*}{$\begin{array}{l}\text { We should keep the voting } \\
\text { system as it is }\end{array}$} & Per cent & 46.1 & 39.9 & 29.5 \\
\hline & & Standardised Residual & 1.3 & -.1 & -1.6 \\
\hline & \multirow{3}{*}{ It would make no difference } & Per cent & 30.1 & 23.4 & 11.4 \\
\hline & & Standardised Residual & 1.8 & -.1 & -2.4 \\
\hline & & $N=725$ & $\chi^{2}=34.140$ & $p=.001$ & \\
\hline
\end{tabular}


Table III: Views on non-institutionalised and extra-parliamentary forms of political action*

\begin{tabular}{|c|c|c|c|}
\hline \multicolumn{2}{|c|}{$\begin{array}{l}\text { Being involved with groups like Greenpeace is a better way to influence } \\
\text { government than being active in a party }\end{array}$} & \multirow{2}{*}{$\begin{array}{l}\text { Mean } \\
2.59\end{array}$} & \multirow{2}{*}{$\begin{array}{r}\text { SD } \\
.948\end{array}$} \\
\hline \multirow{4}{*}{2002} & Materialist & & \\
\hline & Mixed & 2.37 & .784 \\
\hline & Postmaterialist & 2.27 & .790 \\
\hline & & \multicolumn{2}{|c|}{$F(2,327)=1.970, p=.141$} \\
\hline \multirow{4}{*}{2011} & Materialist & 2.71 & .770 \\
\hline & Mixed & 2.70 & .922 \\
\hline & Postmaterialist & 2.40 & .980 \\
\hline & & \multicolumn{2}{|c|}{$F(2,904)=5.974, p=.003$} \\
\hline \multicolumn{2}{|c|}{$\begin{array}{l}\text { Being involved with direct action groups is a better way to influence } \\
\text { government than being active in a party } * *\end{array}$} & Mean & SD \\
\hline \multirow{4}{*}{2011} & Materialist & 2.67 & .712 \\
\hline & Mixed & 2.59 & .776 \\
\hline & Postmaterialist & 2.32 & .879 \\
\hline & & \multicolumn{2}{|c|}{$F(2,896)=8.537, p<.001$} \\
\hline \multicolumn{2}{|c|}{$\begin{array}{l}\text { People should be allowed to organise public meetings in protest against the } \\
\text { government }\end{array}$} & Mean & SD \\
\hline \multirow{4}{*}{2002} & Materialist & 1.95 & .649 \\
\hline & Mixed & 1.85 & .618 \\
\hline & Postmaterialist & 1.62 & .589 \\
\hline & & \multicolumn{2}{|c|}{$F(2,468)=7.387, p=.001$} \\
\hline \multirow{4}{*}{2011} & Materialist & 1.94 & .636 \\
\hline & Mixed & 1.76 & .620 \\
\hline & Postmaterialist & 1.48 & .552 \\
\hline & & \multicolumn{2}{|c|}{$F(2,750)=20.087, p<.001$} \\
\hline
\end{tabular}

* Low mean scores indicate high support

** Question not asked in the 2002 study 
Table IV: Mean likelihood of taking part in political actions in the next few years for postmaterialists, materialists and mixed groups (1 - 5 scale, where 1 means very unlikely and 5 means very likely)

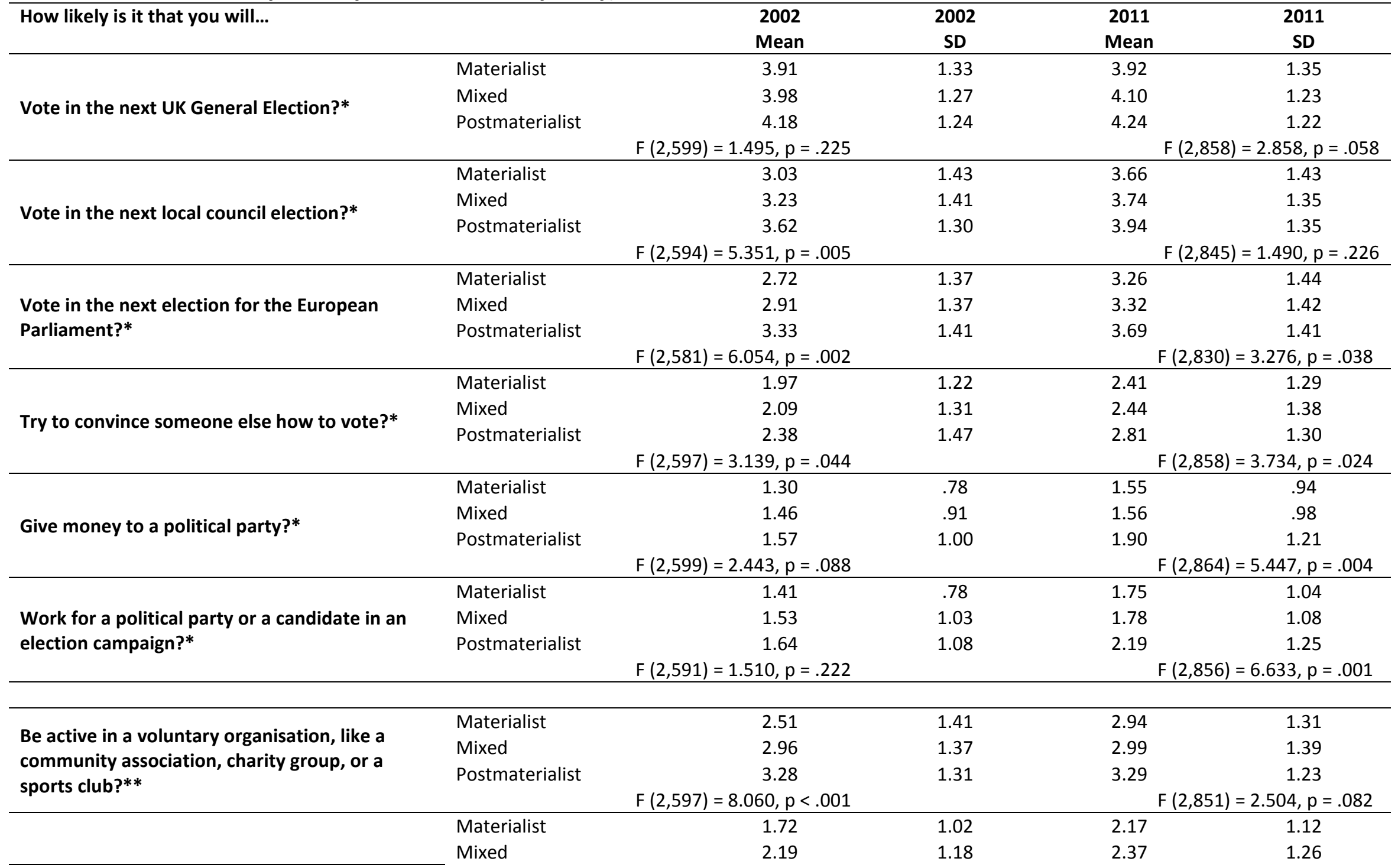




\begin{tabular}{|c|c|c|c|c|c|}
\hline $\begin{array}{l}\text { Participate in a protest, like a rally or a } \\
\text { demonstration, to show your concern about a } \\
\text { public issue or problem?** }\end{array}$ & \multicolumn{3}{|c|}{$F(2,596)=15.658, p<.001$} & \multicolumn{2}{|c|}{$F(2,850)=16.746, p<.001$} \\
\hline \multirow{4}{*}{$\begin{array}{l}\text { Work actively with a group of people to address } \\
\text { a public issue or tackle a problem?** }\end{array}$} & Materialist & 1.84 & 1.00 & 2.19 & 1.08 \\
\hline & Mixed & 2.22 & 1.14 & 2.36 & 1.12 \\
\hline & Postmaterialist & 2.60 & 1.13 & 2.78 & 1.16 \\
\hline & \multicolumn{3}{|c|}{$F(2,598)=12.215, p<.001$} & \multicolumn{2}{|c|}{$F(2,835)=9.819, p<.001$} \\
\hline \multirow{4}{*}{ Discuss politics with family or friends?** } & Materialist & 3.03 & 1.36 & 3.60 & 1.23 \\
\hline & Mixed & 3.37 & 1.45 & 3.70 & 1.27 \\
\hline & Postmaterialist & 3.78 & 1.28 & 4.10 & 1.17 \\
\hline & \multicolumn{3}{|c|}{$F(2,594)=7.669, p=.001$} & \multicolumn{2}{|c|}{$F(2,870)=6.252, p=.002$} \\
\hline \multirow{4}{*}{ Get involved in a youth council or forum?** } & Materialist & 1.78 & 1.03 & 2.35 & 1.14 \\
\hline & Mixed & 1.96 & 1.13 & 2.47 & 1.25 \\
\hline & Postmaterialist & 2.31 & 1.21 & 3.03 & 1.24 \\
\hline & \multicolumn{3}{|c|}{$F(2,598)=6.635, p=.001$} & \multicolumn{2}{|c|}{$F(2,855)=11.680, p<.001$} \\
\hline
\end{tabular}

* Election-oriented institutionalised political participation variables

** Alternative non-institutionalised political participation variables 
Table V: Impact of economic conditions on the mean likelihood of taking part in political actions in the next few years for postmaterialists and materialists $(1-5$ scale, where 1 means very unlikely and 5 means very likely)

2002

2011

\begin{tabular}{llllll}
$\begin{array}{l}\text { Mean } \\
\text { materialist- } \\
\text { postmaterialist } \\
\text { difference }\end{array}$ & $\begin{array}{l}\text { Standard } \\
\text { Error }\end{array}$ & $\begin{array}{l}\text { Mean } \\
\text { materialist- } \\
\text { postmaterialist } \\
\text { difference }\end{array}$ & $\begin{array}{l}\text { Standard } \\
\text { Error }\end{array}$ & F & P \\
\hline-.412 & .117 & -.429 & .102 & .012 & .912 \\
-.740 & .120 & -.637 & .098 & .433 & .511 \\
\hline
\end{tabular}

Non-institutionalised forms of political participation

Institutionalised forms of

political participation 
Table VI: Postmaterialism, socio-demographic background and political participation under economic prosperity (2002) and austerity (2011) conditions

\begin{tabular}{|c|c|c|c|c|c|c|c|}
\hline \multirow[b]{2}{*}{$\begin{array}{l}\text { Dependent } \\
\text { Variable }\end{array}$} & \multirow[b]{2}{*}{ Independent variables } & \multicolumn{3}{|c|}{2002} & \multicolumn{3}{|c|}{2011} \\
\hline & & B & Beta & $\mathbf{P}$ & B & Beta & $\mathbf{P}$ \\
\hline Vote in the UK & Materialism/Postmaterialism & .113 & .053 & .238 & .176 & .084 & .011 \\
\hline General & Gender & -121 & -.047 & .290 & .032 & .012 & .709 \\
\hline \multirow[t]{4}{*}{ Election } & Ethnicity & .083 & .012 & .786 & -.056 & -.014 & .663 \\
\hline & Qualifications & -.533 & -.093 & .039 & -.190 & -.071 & .033 \\
\hline & Time spent in full-time education & .258 & .099 & .032 & .543 & .194 & .000 \\
\hline & Social class & .238 & .095 & .037 & .221 & .086 & .010 \\
\hline \multirow{6}{*}{$\begin{array}{l}\text { Vote in next } \\
\text { local council } \\
\text { election }\end{array}$} & Materialism/Postmaterialism & .265 & .113 & .014 & .159 & .069 & .041 \\
\hline & Gender & .079 & .028 & .533 & -.035 & -.012 & .711 \\
\hline & Ethnicity & .278 & .037 & .415 & .194 & .045 & .178 \\
\hline & Qualifications & -.353 & -.056 & .218 & -.142 & -.048 & .156 \\
\hline & Time spent in full-time education & .200 & .069 & .135 & .421 & .136 & .000 \\
\hline & Social class & .005 & .002 & .969 & .188 & .066 & .050 \\
\hline \multirow{6}{*}{$\begin{array}{l}\text { Vote in } \\
\text { European } \\
\text { Parliament } \\
\text { election }\end{array}$} & Materialism/Postmaterialism & .325 & .138 & .002 & .176 & .071 & .036 \\
\hline & Gender & .061 & .022 & .626 & -.109 & -.036 & .290 \\
\hline & Ethnicity & .366 & .048 & .274 & .009 & .002 & .954 \\
\hline & Qualifications & -.431 & -.067 & .134 & -.107 & -.034 & .321 \\
\hline & Time spent in full-time education & .340 & .117 & .011 & .502 & .150 & .000 \\
\hline & Social class & .329 & .118 & .009 & .032 & .010 & .762 \\
\hline \multirow{6}{*}{$\begin{array}{l}\text { Convince } \\
\text { someone how } \\
\text { to vote }\end{array}$} & Materialism/Postmaterialism & .255 & .112 & .013 & .138 & .057 & .094 \\
\hline & Gender & -.254 & -.093 & .037 & .023 & .008 & .820 \\
\hline & Ethnicity & .204 & .028 & .531 & .282 & .063 & .065 \\
\hline & Qualifications & -.494 & -.081 & .071 & .084 & .027 & .426 \\
\hline & Time spent in full-time education & .085 & .031 & .505 & .216 & .066 & .055 \\
\hline & Social class & .281 & .105 & .021 & .085 & .029 & .403 \\
\hline \multirow{6}{*}{$\begin{array}{l}\text { Give money to } \\
\text { a political party }\end{array}$} & Materialism/Postmaterialism & .153 & .101 & .026 & .178 & .086 & .011 \\
\hline & Gender & .168 & .092 & .041 & .064 & .025 & .460 \\
\hline & Ethnicity & -.090 & -.018 & .681 & .296 & .078 & .022 \\
\hline & Qualifications & -.108 & -.027 & .558 & .010 & .004 & .912 \\
\hline & Time spent in full-time education & .098 & .053 & .254 & .021 & .008 & .823 \\
\hline & Social class & -.054 & -.030 & .514 & -.120 & -.047 & .165 \\
\hline \multirow{6}{*}{$\begin{array}{l}\text { Work for a } \\
\text { political party }\end{array}$} & Materialism/Postmaterialism & .106 & .063 & .173 & .245 & .110 & .001 \\
\hline & Gender & .011 & .005 & .905 & -.061 & -.023 & .507 \\
\hline & Ethnicity & -.195 & -.036 & .431 & .308 & .075 & .027 \\
\hline & Qualifications & -.194 & -.043 & .351 & -.113 & -.040 & .241 \\
\hline & Time spent in full-time education & .042 & .020 & .670 & -.089 & -.030 & .388 \\
\hline & Social class & .057 & .028 & .541 & -.163 & -.060 & .080 \\
\hline \multirow{6}{*}{$\begin{array}{l}\text { Be active in a } \\
\text { voluntary } \\
\text { organisation }\end{array}$} & Materialism/Postmaterialism & .401 & .171 & .000 & .117 & .049 & .151 \\
\hline & Gender & .018 & .007 & .880 & .152 & .052 & .128 \\
\hline & Ethnicity & .322 & .043 & .327 & .067 & .015 & .656 \\
\hline & Qualifications & -.176 & -.028 & .523 & .048 & .016 & .644 \\
\hline & Time spent in full-time education & .378 & .132 & .003 & .124 & .039 & .263 \\
\hline & Social class & .360 & .131 & .003 & .221 & .075 & .028 \\
\hline \multirow{8}{*}{$\begin{array}{l}\text { Participate in a } \\
\text { protest }\end{array}$} & Materialism/Postmaterialism & .465 & .226 & .000 & .437 & .185 & .000 \\
\hline & Gender & .076 & .031 & .484 & .072 & .025 & .453 \\
\hline & Ethnicity & .421 & .064 & .147 & .383 & .088 & .009 \\
\hline & Qualifications & .126 & .023 & .604 & .002 & .001 & .986 \\
\hline & Time spent in full-time education & .173 & .069 & .128 & .316 & .100 & .003 \\
\hline & Social class & .209 & .086 & .054 & -.069 & -.024 & .480 \\
\hline & Materialism/Postmaterialism & .424 & .226 & .000 & .244 & .106 & .002 \\
\hline & Gender & .152 & .068 & .126 & .228 & .081 & .016 \\
\hline
\end{tabular}




\begin{tabular}{|c|c|c|c|c|c|c|c|}
\hline \multirow{4}{*}{$\begin{array}{l}\text { Work actively } \\
\text { to address a } \\
\text { public issue }\end{array}$} & Ethnicity & -.147 & -.024 & .591 & .508 & .119 & .000 \\
\hline & Qualifications & .022 & .004 & .921 & -.038 & -.013 & .703 \\
\hline & Time spent in full-time education & .127 & .055 & .225 & .255 & .082 & .016 \\
\hline & Social class & .077 & .035 & .438 & .033 & .012 & .728 \\
\hline \multirow{6}{*}{$\begin{array}{l}\text { Discuss politics } \\
\text { with family or } \\
\text { friends }\end{array}$} & Materialism/Postmaterialism & .359 & .150 & .001 & .213 & .101 & .003 \\
\hline & Gender & -.092 & -.032 & .464 & .220 & .086 & .011 \\
\hline & Ethnicity & .567 & .074 & .092 & -.192 & -.050 & .140 \\
\hline & Qualifications & .287 & .045 & .309 & -.229 & -.085 & .011 \\
\hline & Time spent in full-time education & .339 & .116 & .010 & .227 & .081 & .018 \\
\hline & Social class & .494 & .175 & .000 & .104 & .040 & .232 \\
\hline \multirow{6}{*}{$\begin{array}{l}\text { Get involved } \\
\text { with a youth } \\
\text { council or } \\
\text { forum }\end{array}$} & Materialism/Postmaterialism & .295 & .155 & .001 & .296 & .129 & .000 \\
\hline & Gender & .063 & .028 & .535 & .262 & .093 & .005 \\
\hline & Ethnicity & .395 & .062 & .159 & .599 & .141 & .000 \\
\hline & Qualifications & -.465 & -.091 & .043 & -.108 & -.037 & .270 \\
\hline & Time spent in full-time education & .133 & .057 & .213 & .241 & .078 & .021 \\
\hline & Social class & .118 & .053 & .244 & -.095 & -.033 & .317 \\
\hline
\end{tabular}

Note: Highlighted figures are statistically significant $(p<0.05)$

\section{Notes}

i Details withheld to maintain the anonymity of the author during the peer review process.

ii It should be noted that following Inglehart's expectations, we would expect the political participation preferences of the 'mixed' group to sit between the 'materialist' and the 'postmaterialist' groups. This is so in all cases except for Table I year 2002, where the order is mixed, materialist and then postmaterialist.

iii This question was not asked in the 2002 study.

\section{Bibliography}

Barnes, S. H., Kaase, M. et al. 1979 Political Action: Mass Participation in Five Western Democracies, Sage: Beverly Hills, CA.

Bastedo, H. 2015 'Not “One of Us": Understanding How Non-Engaged Youth Feel About Politics and Political Leadership', Journal of Youth Studies 18(5): 649-665.

Bauman, Z. 1999 In Search of Politics, Cambridge: Polity Press. 
Beck, U. 1992 Risk Society: Towards a New Modernity, Sage: London.

Beck, U. and Beck-Gernsheim, E. 2002 Individualization: Institutionalised Individualism and its Social and Political Consequences, London: Sage.

Bentley, T., Oakley, K., Gibson, S. and Kilgour, K. 1999 The Real Deal: What Young People Really Think About Government, Politics and Social Exclusion, DEMOS: London.

Berry, C. 2012 'The Rise of Gerontocracy: Addressing the Intergenerational Democratic Deficit', Intergenerational Foundation http://www.if.org.uk/wpcontent/uploads/2012/04/IF Democratic Deficit final.pdf [Accessed 21 February 2017].

Birch, S., Gottfried, G. and Lodge G. 2013 Divided Democracy: Political Inequality in the UK and Why It Matters, Institute of Public Policy Research: London.

Brym, R. 2016 'After Postmaterialism: An Essay on China, Russia and the United States', Canadian Journal of Sociology 41(2): 195-211.

Busse, B., Hashem-Wangler. A. and Tholen, J. 2015 'Two Worlds of Participation: Young People and Politics in Germany', The Sociological Review 63(S2): 118-140.

Cameron, S. M. 2013 'Postmaterialism in Times of Crisis', paper presented at the European Consortium for Political Research General Conference, Bordeaux.

Copeland, L. 2014 'Value Change and Political Action: Postmaterialism, Political Consumerism and Political Participation', American Politics Research 42(2): 257-282.

Dar, A. 2013 'Elections: Turnout', House of Commons Library http://www.parliament.uk/briefing-papers/SN01467.pdf [Accessed 11 August 2016].

Della Porta, D. 2006 Social Movements. 2nd ed., Malden (MA): Blackwell.

Farthing, R. 2010 'The Politics of Youthful Antipolitics: Representing the "Issue" of Youth Participation in Politics', Journal of Youth Studies 13(2): 181-195. 
Flanagan, C., Finlay, A., Gallay, L. and Kim, T. 2012 'Political Incorporation and the Protracted Transition to Adulthood: The Need for New Institutional Inventions', Parliamentary Affairs 65(1): 29-46.

Fox, S. 2016 'The Campaigns Are Having an Effect - And it's Bad News for Bremainers', http://blogs.cardiff.ac.uk/wiserd/2016/05/13/the-campaigns-are-having-an-effect-and-its-badnews-for-bremainers/ [Accessed 21 February 2017].

Furlong, A. and Cartmel, F. 2012 'Social Change and Political Engagement Among Young People: Generation and the 2009/2010 British Election Survey', Parliamentary Affairs 65(1): 13-28.

Giddens, A. 1991 Modernity and Self-Identity: Self and Society in the Late Modern Age, Polity Press: Cambridge.

Grasso, M. T. 2014 'Age, Period and Cohort Analysis in a Comparative Context: Political Generations and Political Participation Repertoires in Western Europe', Electoral Studies 33(1): 6376.

Grimm, R. and Pilkington, H. 2015 “'Loud and Proud": Youth and the Politics of Silencing', The Sociological Review 63(S2): 206-230.

Halvorsen, S. 2012 'Beyond the Network? Occupy London and the Global Movement', Social Movement Studies: Journal of Social, Cultural and Political Protest 11(3-4): 427-433.

Hansard Society 2016 'Audit of Political Engagement 13: The 2016 Report', Hansard Society https://www.hansardsociety.org.uk/publications/audit-of-political-engagement-13-the-2016report [Accessed 21 February 2017].

Hay, C. (2007). Why We Hate Politics, Polity Press: Cambridge.

Heath, A., Fisher, S., Sanders, D. and Sobolewska, M. 2011 'Ethnic Heterogeneity in the Social Bases of Voting at the 2010 British General Election', Journal of Elections, Public Opinion and Parties 21(2): 255-277. 
Helm, T. 2016 'EU Referendum: Youth Turnout Almost Twice as High as First Thought', The Guardian

Online 10 July http://www.theguardian.com/politics/2016/jul/09/young-people-referendumturnout-brexit-twice-as-high [Accessed 21 February 2017].

Henn, M. and Foard, N. 2014 'Social Differentiation in Young People's Political Participation: The Impact of Social and Educational Factors on Youth Political Engagement in Britain', Journal of Youth Studies 17(3), 360-380.

Henn, M. and Oldfield, B. 2016 'Cajoling or Coercing: Would Electoral Engineering Solve the Young Citizen-State Disconnect?', Journal of Youth Studies 19(9): 1259-1280.

Henn, M., Weinstein, M. and Forrest, S. 2005 'Uninterested Youth? Young People's Attitudes Towards Party Politics in Britain', Political Studies 53(3): 556-578.

Holmes, M. and Manning, N. 2013 “"Them That Runs the Country Don't Know What They're Doing”: Political Dissatisfaction Amongst Members of the White Working Class', The Sociological Review 61(3), 479-498.

Hopkins, P., Todd, I. and Newcastle Occupation. 2011 'Occupying Newcastle University: Student Resistance to Government Spending Cuts in England', The Geographical Journal 178(2): 104-9.

Inglehart, R. 1971 'The Silent Revolution in Europe: Intergenerational Change in Post-Industrial Societies', American Political Science Review 65(4): 991-1017.

Inglehart, R. 1990 Culture Shift in Advanced Industrial Society, Princeton University Press: Princeton. Inglehart, R. 2016 'Inequality and Modernization: Why Equality Is Likely to Make a Comeback', Foreign Affairs 95(1): 2-10.

Inglehart, R. and Catterberg, G. 2003 'Trends in Political Action: The Developmental Trend and the Post-Honeymoon Decline', International Journal of Comparative Sociology 43(3-5): 300-316.

Inglehart, R. and Welzel, C. 2005 Modernization, Cultural Change, and Democracy: The Human Development Sequence, Cambridge University Press: New York. 
Ipsos MORI 2015 'How Britain Voted in 2015: The 2015 election - Who Voted for Whom?', Ipsos MORI https://www.ipsos-mori.com/researchpublications/researcharchive/3575/How-Britainvoted-in-2015.aspx?view=wide [Accessed 21 February 2017].

Janmaat, J. G. 2016 'Values in Times of Austerity: A Cross-National and Cross-Generational Analysis', Citizenship Teaching \& Learning 11(3): 267-87.

Li, Y. and Marsh, D. 2008 'New Forms of Political Participation: Searching for Expert Citizens and Everyday Makers', British Journal of Political Science 38(2): 247-272.

Majima, S. and Savage, M. 2007 'Have There Been Culture Shifts in Britain? A Critical Encounter with Ronald Inglehart', Cultural Sociology 1(3): 293-315.

Marien, S., Hooghe, M. and Quintelier, E. 2010 'Inequalities in Non-Institutionalised Forms of Political Participation: A Multi-Level Analysis of 25 Countries', Political Studies 58(1): 187-213.

Marsh, D., O’Toole, T. and Jones, S. 2007 Young People and Politics in the UK. Apathy or Alienation?. Palgrave Macmillan: Basingstoke.

Melo, D.F. and Stockemer, D. 2014 'Age and Political Participation in Germany, France and the UK: A Comparative Analysis', Comparative European Politics 12(1): 33-53.

Norris, P. 2011 Democratic Deficit: Critical Citizens Revisited, Cambridge University Press: Cambridge.

Norris, P. and Inglehart, R. 2009 Cosmopolitan Communications: Cultural Diversity in a Globalised World, Cambridge University Press: Cambridge.

ONS 2016a 'Gross Domestic Product: Year on Year growth: CVM SA \%', ONS https://www.ons.gov.uk/economy/grossdomesticproductgdp/timeseries/ihyp/pgdp_Accessed 21 February 2017].

ONS 2016b 'Wages and salaries annual growth rate \%', ONS https://www.ons.gov.uk/economy/grossdomesticproductgdp/timeseries/kgq2/qna [Accessed 21 February 2017]. 
ONS 2016c 'Unemployment rate (aged 16 and over, seasonally adjusted)', ONS https://www.ons.gov.uk/employmentandlabourmarket/peoplenotinwork/unemployment/timeser ies/mgsx/Ims [Accessed 21 February 2017].

Parigi, P. and Gong, R. 2014 'From Grassroots to Digital Ties: A Case Study of a Political Consumerism Movement', Journal of Consumer Culture 14(2): 236-253.

Pattie, C., Seyd, P., and Whiteley, P. 2004 Citizenship in Britain: Values, Participation and Democracy, Cambridge University Press: Cambridge.

Phelps, E. 2012 'Understanding Electoral Turnout Among British Young People: A Review of the Literature', Parliamentary Affairs 64(1): 281-299.

Quintelier, E. 2007 'Differences in Political Participation Between Young and Old People', Contemporary Politics 13(2): 165-180.

Sloam, J. 2007 'Rebooting Democracy: Youth Participation in Politics in the UK', Parliamentary Affairs 60(4): 548-567.

Sloam, J. 2014 'New Voice, Less Equal: The Civic and Political Engagement of Young People in the United States and Europe', Comparative Political Studies 47(5): 663-688.

Soler-i-Martí, R. 2015 'Youth Political Involvement Update: Measuring the Role of Cause-Orientated Political Interest in Young People's Activism', Journal of Youth Studies 18(3): 396-416.

Stoker, G. 2006 Why Politics Matters: Making Democracy Work, Basingstoke: Palgrave Macmillan. Stolle, D., Hooghe, M. and Micheletti, M. 2005 'Politics in the Supermarket: Political Consumerism as a Form of Political Participation', International Political Science Review 26(3): 245-269.

Tenn, S. 2007 'The Effect of Education on Voter Turnout', Political Analysis 15(4): 446-464.

The Electoral Commission 2014 'Scottish Independence Referendum', The Electoral Commission http://www.electoralcommission.org.uk/ data/assets/pdf file/0010/179812/Scottishindependence-referendum-report.pdf [Accessed 21 February 2017]. 
Theocharis, Y. 2011 'The Influence of Postmaterialist Orientations on Young People's Offline and Online Political Participation', Representation 47(4): 435-455.

Tormey, S. 2015 The End of Representative Politics, Cambridge: Polity Press.

Verba, S. and Nie, N. 1972 Participation in America, Harper and Row: New York.

Vromen, A., Xenos, M. A. and Loader, B. 2015 'Young People, Social Media and Connective Action: From Organisational Maintenance to Everyday Political Talk', Journal of Youth Studies 18(1): 80-100.

White, C., Bruce, S. and Ritchie, J. 2000 Young People's Politics_Political Interest and Engagement Amongst 14-24 year olds, The Joseph Rowntree Foundation: York.

Whiteley, P. 2012 Political Participation in Britain, Palgrave Macmillan: Basingstoke.

YouGov 2016 'YouGov Survey Results', YouGov

http://d25d2506sfb94s.cloudfront.net/cumulus uploads/document/640yx5m0rx/On the Day FI NAL poll forwebsite.pdf [Accessed 21 February 2017].

Zukin, C., Keeter, S., Andolina, M., Jenkins, K. and Delli Carpini, M. X. 2006 A New Engagement? Political Participation, Civic Life, and the Changing American Citizen, Oxford University Press: New York. 